\title{
Growth, Yield and Quality Parameters of Green Gram (Vigna radiata L.) as Influenced by Graded Levels of Potassium
}

\author{
Tyngshain Kharkongor and A. L. Dhamak ${ }^{*}$ \\ Department of Soil Science and Agricultural Chemistry, Vasantrao Naik Marathwada Krishi \\ Vidyapeeth, Parbhani -431402, Maharashtra, India \\ *Corresponding author
}

\section{A B S T R A C T}

K e y w o r d s
Potassium,
Micronutrient,
Growth, Yield,
Quality, Green
gram

\section{Introduction}

Potassium is one of the major essential plant nutrients which play a vital role in various physiological and biochemical activities and required in high amounts to maintain adequate crop growth and sustainable crop production (Mengel and Kirkby, 2001). The adequate supply of potassium during growth period improves the water relations of plant and photosynthesis (Garg et al., 2005), maintains turgor pressure of cell which is necessary for cell expansion, helps in osmotic-regulation of plant cell, assists in opening and closing of stomata, activates more than 60 enzymes, synthesizes protein, provides resistance against diseases and pest (Arif et al., 2008) and enhances the mungbean yield (Ali et al., 2010). Indian soils vary widely in their $\mathrm{K}$ status due to differences in origin of parent material and mineralogical make up and variation in readily available $\mathrm{K}$ and non exchangeable $\mathrm{K}$ reserves and the soils are expected to behave differently with respect to supply of $\mathrm{K}$ to plants. Crop response to $\mathrm{K}$ depends on $\mathrm{K}$ supplying power of soil and $\mathrm{K}$ requirements of crop and on growing conditions. Vertisols and associated 
soils with relatively low levels of non exchangeable to exchangeable $\mathrm{K}$, have higher available $\mathrm{K}$ but, low to medium non exchangeable $\mathrm{K}$ which under long term cropping, may get depleted faster. In soils with low levels of both exchangeable and non exchangeable $\mathrm{K}$, $\mathrm{K}$ application must be done to realize full yield potential of crops (Srinivasarao et al., 2010). Potassium is barely applied to pulse crops despite larger $\mathrm{K}$ requirement of pulses and continued mining of soil potassium resulting in imbalanced nutrient supply and lower crop yield. Among production inputs, fertilizer application plays a key role in enhancing productivity levels. However, fertilizer recommendation practices for pulse crops have been paid less attention. There has been a dramatic decrease in the fertilizer consumption of $\mathrm{K}$ compared to fertilizer $\mathrm{N}$ and $\mathrm{P}$ while $\mathrm{K}$ removal from the soil is generally as much as or higher than $\mathrm{N}$ still its use in fertilizer is negligible. In general, farmers apply low rates of nitrogen $(\mathrm{N})$ and phosphorus $(\mathrm{P})$, but potassium $(\mathrm{K})$ is frequently absent from their fertilizer schedule. This lack of $\mathrm{K}$ is responsible for low yields and poor crop quality because apart from other major physiological and biochemical requirements in plant growth, $\mathrm{K}$ is a key nutrient element in the biosynthesis of oil in oilseeds and protein in pulse crops. Micronutrients like iron, zinc, manganese, copper, molybdenum, cobalt and boron play an important role in increasing legumes yield through their effect on the plant itself, nitrogen fixing symbiotic process and effective use of major and secondary nutrients. In addition, iron ( $\mathrm{Fe})$, boron (B), zinc $(\mathrm{Zn})$, copper $(\mathrm{Cu})$, and manganese $(\mathrm{Mn})$ are considered essential micronutrients for plants and can maintain crop-physiology balance (Salih, 2013).

Mungbean needs $\mathrm{N}, \mathrm{P}, \mathrm{K}$ and few trace elements for satisfactory growth and production. Keeping in view the importance of potash and micronutrients for plants, this study has been formulated to investigate the effect of potassium levels micronutrients on growth, yield and quality parameters of green gram.

\section{Materials and Methods}

The field experiment was conducted during kharif season 2016-2017 on a Vertisols soil at research farm of Vasantrao Naik Marathwada Krishi Vidyapeeth, Parbhani, Maharashtra, which is located at $76^{\circ} 46^{\prime}$ East longitude and $19^{0} 16^{\prime}$ North latitude, having elevation of $408.5 \mathrm{~m}$ above mean sea level. The soil of the experimental site was classified as Typic Haplustert having pH 7.79, EC $0.24 \mathrm{dSm}^{-1}$, organic carbon $4.10 \mathrm{~g} \mathrm{~kg}^{-1}$ and calcium carbonate $52.00 \mathrm{~g} \mathrm{~kg}^{-1}$. Available soil $\mathrm{N}, \mathrm{P}$ and $\mathrm{K}$ were $197.57,9.72$ and $727.78 \mathrm{~kg} \mathrm{ha}^{-1}$, respectively. The experimental soil has sufficient amount of available Mn $(3.60 \mathrm{mg}$ $\left.\mathrm{kg}^{-1}\right)$ and $\mathrm{Cu}\left(2.43 \mathrm{mg} \mathrm{kg}^{-1}\right)$ and deficient in Fe (1.44 $\left.\mathrm{mg} \mathrm{kg}^{-1}\right)$ and $\mathrm{Zn}\left(0.68 \mathrm{mg} \mathrm{kg}^{-1}\right)$. The experiment was laid out in randomized block design (RBD) with eight treatments and three replications. The treatment consists of $\mathrm{T}_{1}$ Absolute control, $\mathrm{T}_{2}$ - Only RDF (25:50 $\left.\mathrm{N}: \mathrm{P}_{2} \mathrm{O}_{5} \mathrm{~kg} \mathrm{ha}^{-1}\right), \mathrm{T}_{3}-\mathrm{RDF}+25 \mathrm{~kg} \mathrm{~K}_{2} \mathrm{O} \mathrm{ha}{ }^{-1}$, $\mathrm{T}_{4}-\mathrm{RDF}+50 \mathrm{~kg} \mathrm{~K}_{2} \mathrm{O} \mathrm{ha}^{-1}, \mathrm{~T}_{5}-\mathrm{RDF}+25 \mathrm{~kg}$ $\mathrm{K}_{2} \mathrm{O} \mathrm{ha}^{-1}+$ Grade I micronutrient (soil application), $\mathrm{T}_{6}-\mathrm{RDF}+50 \mathrm{~kg} \mathrm{~K} \mathrm{O} \mathrm{ha}^{-1}+$ Grade I micronutrient (soil application), $\mathrm{T}_{7}$ $\mathrm{RDF}+25 \mathrm{~kg} \mathrm{~K}_{2} \mathrm{O} \mathrm{ha}^{-1}+$ Grade II $(0.5 \%)$ micronutrient (foliar spray), $\mathrm{T}_{8}-\mathrm{RDF}+50 \mathrm{~kg}$ $\mathrm{K}_{2} \mathrm{O}$ ha $^{-1}+$ Grade II $(0.5 \%)$ micronutrient (foliar spray). Green gram variety BM-4 was sown at $45 \mathrm{~cm} \times 5 \mathrm{~cm}$ spacing. The recommended dose of fertilizer was $25: 50 \mathrm{~kg}$ $\mathrm{N}$ and $\mathrm{P}_{2} \mathrm{O}_{5} \mathrm{ha}^{-1}$. The RDF, $\mathrm{K}_{2} \mathrm{O}$ and micronutrient grade I fertilizers were applied through soil application at the time of sowing. The micronutrient grade II fertilizer was applied as foliar spray at 20 and 35 days after sowing (DAS). 
The data recorded pertaining to grain yield and quality parameters were analyzed statistically for interpreting the results. In order to know the nutrient status of the experimental site, the soil samples to the depth of $0-15 \mathrm{~cm}$ were randomly collected from the experimental site before sowing and after harvesting of crop. The analysis of plant samples was carried out as per the standard methods. Five plants were randomly selected from each plot, tagged and all biometric observations were recorded.

\section{Results and Discussion}

\section{Growth and yield attributes}

The growth and yield parameters like plant height, leaf area, number of nodules per plant, fresh weight of nodules per plant, total biomass production, number of pods per plant, economic yield and dry matter yield showed significant increase when green gram received $\mathrm{RDF}+50 \mathrm{~kg} \mathrm{~K}_{2} \mathrm{O} \mathrm{ha}^{-1}+$ Grade I micronutrient followed by application of RDF $+50 \mathrm{~kg} \mathrm{~K}_{2} \mathrm{O} \mathrm{ha}^{-1}+$ Grade II micronutrient, which was significantly higher over control and application of RDF i.e. only $\mathrm{N}$ and $\mathrm{P}$ (Table 1).

Treatments $T_{6}, T_{8}, T_{7}$ and $T_{5}$ were found to be statistically at par with each other and superior over rest of the treatments. Potassium application showed significant increase in grain yield of green gram in all the treatments over control $\left(\mathrm{T}_{1}\right)$ and only $\operatorname{RDF}\left(\mathrm{T}_{2}\right)$. The highest yield was obtained by the application of $\mathrm{RDF}+50 \mathrm{~kg} \mathrm{~K} \mathrm{~K}_{2} \mathrm{O} \mathrm{ha}{ }^{-1}+$ Grade I micronutrient $\left(1207.51 \mathrm{~kg} \mathrm{ha}^{-1}\right)$ followed by $\mathrm{RDF}+50 \mathrm{~kg} \mathrm{~K}_{2} \mathrm{O} \mathrm{ha} \mathrm{ha}^{-1}+$ Grade II micronutrient (1198.35 $\left.\mathrm{kg} \mathrm{ha}^{-1}\right)$ and $\mathrm{RDF}+25$ $\mathrm{kg} \mathrm{K}_{2} \mathrm{O} \mathrm{ha}^{-1}+$ Grade II micronutrient $\left(1162.96 \mathrm{~kg} \mathrm{ha}^{-1}\right)$ which were found to be statistically at par with each other. The one year data showed that application of $25 \mathrm{~kg}$ or $50 \mathrm{~kg} \mathrm{~K}_{2} \mathrm{O} \mathrm{ha}^{-1}$ recorded statistically at par on grain yield. The application of graded levels of potassium and Grade I or Grade II micronutrient with recommended dose of $\mathrm{N}$ and $\mathrm{P}_{2} \mathrm{O}_{5}\left(25: 50 \mathrm{~kg} \mathrm{ha}^{-1}\right)$ recorded increase in yield. Treatment $\mathrm{T}_{6}$ comprises RDF with 50 $\mathrm{kg} \mathrm{K}_{2} \mathrm{O}$ and Grade I micronutrient fertilizer application produced $1207.51 \mathrm{~kg} \mathrm{ha}^{-1}$ grain yield which was found to be statistically at par with all the treatments receiving potassium. However, it is significantly superior over absolute control $\left(\mathrm{T}_{1}\right)$ and only $\operatorname{RDF}\left(\mathrm{T}_{2}\right)$.

\section{Quality parameters}

The highest seed protein content and test weight was recorded by application of RDF + $50 \mathrm{~kg} \mathrm{~K}_{2} \mathrm{O} \mathrm{ha}^{-1}+$ Grade I micronutrient followed by application of RDF $+50 \mathrm{~kg} \mathrm{~K}_{2} \mathrm{O}$ $\mathrm{ha}^{-1}+$ Grade II micronutrient (Table 1). The lowest protein content was observed in control $\mathrm{T}_{1}(17.03 \%)$. The treatment $\mathrm{T}_{6}$ recorded highest protein content $(21.47 \%)$, followed by treatment $\mathrm{T}_{8}(21.06 \%)$. Improved $\mathrm{K}$ supply is commonly associated with improved protein content in pulse grains, $\mathrm{N}$ fixation and water use efficiency. As potash has synergistic effect on $\mathrm{N}$ and $\mathrm{K}$ uptake, it also facilitates protein synthesis and activates different enzymes. Thereby, protein content increased significantly with increase in $\mathrm{K}$ levels. The highest test weight (30.43 g) was obtained by the application of RDF $+50 \mathrm{~kg}$ $\mathrm{K}_{2} \mathrm{O}$ ha $^{-1}+$ Grade I micronutrient which is significantly superior over control (28.83 g). Treatments $\mathrm{T}_{6}, \mathrm{~T}_{8}, \mathrm{~T}_{7}$ and $\mathrm{T}_{5}$ were found to be statistically at par with each other.

The significant increase in growth and yield attributes with potash application can be attributed to the fact that potash enhances plant vigour and strengthen the stalk. Potash is known to augment cell division and cell expansion resulting in increasing positive effect of growth parameter. 
Table.1 Effect of graded levels of potassium on growth, yield and quality parameters of green gram

\begin{tabular}{|c|c|c|c|c|c|c|c|c|c|c|}
\hline Treatments & $\begin{array}{l}\text { Plant } \\
\text { height } \\
(\mathrm{cm})\end{array}$ & $\begin{array}{l}\text { Leaf } \\
\text { Area } \\
\left(\mathrm{cm}^{2}\right)\end{array}$ & $\begin{array}{c}\text { No. of } \\
\text { nodules }\end{array}$ & $\begin{array}{l}\text { Fresh weight } \\
\text { of nodules } \\
\left(\text { g plant }^{-1}\right)\end{array}$ & $\begin{array}{l}\text { No. of pods } \\
\text { per plant }\end{array}$ & $\begin{array}{c}\text { Dry } \\
\text { matter } \\
\left(\mathrm{kg} \mathrm{ha}^{-1}\right)\end{array}$ & $\begin{array}{c}\text { Economic } \\
\text { yield } \\
\left(\mathrm{kg} \mathrm{ha}^{-1}\right)\end{array}$ & $\begin{array}{c}\text { Biomass } \\
\text { production } \\
\left(\text { g plant }^{-1}\right)\end{array}$ & $\begin{array}{c}\text { Test } \\
\text { weight } \\
\text { (g) }\end{array}$ & $\begin{array}{c}\text { Protein } \\
(\%)\end{array}$ \\
\hline $\mathbf{T 1}$ & 48.67 & 93.55 & 32.13 & 0.17 & 6.93 & 2527.41 & 762.65 & 11.94 & 28.83 & 17.03 \\
\hline $\mathbf{T 2}$ & 68.20 & 167.28 & 39.67 & 0.24 & 11.27 & 4485.93 & 1061.93 & 20.43 & 29.10 & 19.54 \\
\hline T3 & 69.33 & 171.27 & 42.80 & 0.27 & 11.47 & 4794.07 & 1094.96 & 21.25 & 29.13 & 19.66 \\
\hline T4 & 69.47 & 176.47 & 48.33 & 0.29 & 11.67 & 5253.33 & 1114.09 & 23.64 & 29.60 & 19.83 \\
\hline T5 & 71.33 & 181.89 & 53.73 & 0.30 & 13.20 & 5360.00 & 1158.02 & 26.26 & 29.70 & 20.36 \\
\hline T6 & 75.07 & 201.23 & 56.87 & 0.36 & 15.60 & 6642.96 & 1207.51 & 28.52 & 30.43 & 21.47 \\
\hline T7 & 72.13 & 193.02 & 50.27 & 0.32 & 13.93 & 5478.52 & 1162.96 & 27.22 & 29.87 & 20.53 \\
\hline T8 & 73.87 & 197.83 & 54.27 & 0.34 & 14.40 & 5680.00 & 1198.35 & 28.32 & 29.93 & 21.06 \\
\hline Mean & 68.51 & 172.82 & 47.26 & 0.29 & 12.31 & 5027.78 & 1095.06 & 23.45 & 29.58 & 19.94 \\
\hline $\operatorname{SEm}( \pm)$ & 1.64 & 3.77 & 2.00 & 0.01 & 0.55 & 127.72 & 62.53 & 1.69 & 0.54 & 0.61 \\
\hline CD (5\%) & 4.07 & 9.40 & 4.99 & 0.03 & 1.38 & 318.06 & 155.72 & 4.22 & 1.35 & 1.52 \\
\hline
\end{tabular}


The highest plant height may be due to the positive effects of potassium and micronutrients on the vegetative growth and accumulation of metabolic materials. Similar findings have been reported by Ali et al., (2007) and Kumar et al., (2014). The accumulation of biomass was relatively more at the later part of the crop. This may be attributed to the productive phases of green gram. This may be due to the effect of both potassium and micronutrient application. Potassium plays a major role in growth as it is involved in assimilation, transport, and storage tissue development. These results are in agreement with findings of Salve and Gunjal (2011) and Buriro et al., (2015). The minimum number of pods per plant in absolute control $\left(T_{1}\right)$ might have been due to less availability of $\mathrm{N}$ and $\mathrm{P}$ and stunted growth. Application of $\mathrm{K}$ enhanced the photosynthetic activity which resulted in more number of seeds per pod as compared to control. Improvement of pod bearing capacity of crop could be possibly because of improved $\mathrm{N}$ and $\mathrm{P}$ fertilization efficiency in the presence of $\mathrm{K}$. Increased rate of photosynthetic and symbiotic activity following balanced application of NPK stimulated better vegetative and reproductive growth of the crop resulting in higher pod yield. This might be due to the favourable influence of optimum potash and micronutrient on metabolism and biological activity and its stimulatory effects on growth of plant. Addition of potassium either 25 or $50 \mathrm{~kg} \mathrm{ha}^{-1}$ recorded significant improvement in yield and all parameters contributing grain yield, biomass yield and quality. The grain yield of green gram further increased with soil application of Grade I micronutrient or foliar spray of Grade II micronutrient fertilizer. The positive effect of $\mathrm{K}$ on crop yield might also be due to its requirement in carbohydrate synthesis and translocation of photosynthesis and also may be due to improved yield attributing characters, shoot growth and nodulation. This may be due fact that potassium and micronutrient are reported to enhance the absorption of native as well as added major nutrient such as $\mathrm{N}$ and $\mathrm{P}$ which might have been resulted in improvement in yield. The higher levels of $\mathrm{K}$ supplied sufficient $\mathrm{K}$ to plants which initiated maximum translocation of photosynthates to fruiting zone. Improved $\mathrm{K}$ supply is commonly associated with improved protein content in pulse grains, $\mathrm{N}$ fixation and water use efficiency. As potash has synergistic effect on $\mathrm{N}$ and $\mathrm{K}$ uptake, it also facilitates protein synthesis and activates different enzymes. Thereby, protein content increased significantly with increase in $\mathrm{K}$ levels. Potassium involved in physiological and biochemical functions of plant growth i.e. enzyme activation and protein synthesis and its application in legumes might have improved the nitrogen use efficiency which leads to increase the protein content of the crop.

\section{References}

Ali, A., Nadeem, A. and Hussain, M. (2007). Effect of different potash levels on the growth, yield and protein contents of chickpea (Cicer arietinum L.). Pak. J. Bot., 39(2): 523-527.

Ali, M.A., Abbas, G.Q., Mohyuddin, K., Abbas, G. and Aslam, M. (2010). Response of mungbean (Vigna radiata) to phosphatic fertilizer under arid climate. J. Anim. Plant Sci., 20(2): 8386.

Arif, M., Arshad, M., Khalid, A. and Hannan, A. (2008). Differential response of rice genotypes at deficit and adequate potassium regimes under controlled conditions. Soil Environ., 27(1): 52-57.

Buriro, M., Hussain, F., Talpur, G.H., Gandahi, A.W. and Buriro, B. (2015). Growth and yield response of mungbean varieties to various 
potassium levels. Pak. J. Agri. Agril. Engg. Vet. Sci., 31(2): 203-210.

Garg, B.K., Burmin, U. and Kathju, S. (2005). Physical aspects of drought tolerance in cluster bean and strategies for yield improvement under arid conditions. $J$. Arid Legumes, 2: 61-66.

Kumar, P., Kumar, P., Singh, T., Singh, A.K. and Yadav, R.I. (2014). Effect of different potassium levels on mungbean under custard apple based agri-horti system. Afr. J. Agric. Res., 9(8): 728734.

Mengel, K. and Kirkby, E.A. (2001). Principles of plant nutrition. Dordrecht, the Netherlands: Kluwer Academic Publishers. fertilization of $\mathrm{Fe}, \mathrm{B}$ and $\mathrm{Zn}$ on nutrient concentration and seed protein of cowpea (Vigna unguiculata). J. Agric. Vet. Sci., 6(3): 42-46.

Salve, Y.V. and Gunjal, B.S. (2011). Effect of different levels of phosphorous and potassium on summer groundnut (Arachis hypogaea L.). Intern. J. Agril Sci., 17(2): 352-355.

Srinivasarao, C., Rao, A.S., Rao, K.V., Venkataeswarlu, B. and Singh, A.K., (2010). Categorisation of districts based on non exchangeable potassium. Implications in efficient $\mathrm{K}$ fertility management in Indian Agriculture. Indian J. Fert., 6: 40-54.

Salih, H.O. (2013). Effect of foliar

\section{How to cite this article:}

Tyngshain Kharkongor and Dhamak, A. L. 2020. Growth, Yield and Quality Parameters of Green Gram (Vigna radiata L.) as Influenced by Graded Levels of Potassium. Int.J.Curr.Microbiol.App.Sci. 9(09): 3005-3010. doi: https://doi.org/10.20546/ijcmas.2020.909.371 